\section{'Oregon Star' and 'Oregon Pride' Parthenocarpic Tomatoes}

\author{
James R. Baggett, N.S. Mansour, and Deborah Kean \\ Department of Horticulture, Oregon State University, Corvallis, \\ OR 97331-7304
}

Additional index words. vegetable breeding, tomato fruit set, Lycopersicon esculentum

'Oregon Star' and 'Oregon Pride' are parthenocarpic, determinate tomatoes (Lycopersicon esculentum Mill.). They bear large, nearly seedless fruit with paste tomato characteristics. Because they are early and set fruit relatively well under cool conditions, they are recommended for home gardeners and localmarket growers in cool season areas, such as the Pacific Northwest. 'Oregon Star' and 'Oregon Pride' are essentially the same in fruit characteristics. Greater yield, higher average fruit weight, and better vine cover of the fruit can be expected from 'Oregon Star', but 'Oregon Pride' was released because it can be as much as 1 week earlier and should benefit growers in locations with cool or short seasons.

Origin

'Oregon Star' and 'Oregon Pride' originated from the same $\mathrm{F}_{3}$ selection of the 'Santiam' X 'Roma' cross (Fig. 1). 'Oregon Pride' was tested as an $\mathrm{F}_{7}$ selection, OSU 137 (selected from T77-15-1-4-3 $\mathrm{F}_{6}$ ). 'Oregon Star' is a bulk of two $F_{7}$ selections, OSU 151 and OSU 152 (selected from T77-15-2-2-3 $\mathrm{F}_{6}$ ). Parthenocarpy and earliness were inherited from 'Santiam', which in turn derived these characteristics from 'Severianin' (Baggett and Kean, 1986). We assume that 'Oregon Star' and 'Oregon Pride' carry pat-2, the gene responsible for parthenocarpy in 'Severianin' (Philouze and Maisonneuve, 1978). 'Oregon Star' and 'Oregon Pride' are distinctly different in fruit characteristics from 'Santiam', 'Oregon Spring', and 'Severianin', which are typical multilocular slicing tomatoes with moderately oblate to globular fruit shape. Compared to the paste tomato parent 'Roma', 'Oregon Star' and 'Oregon Pride' fruit are much larger (four times or more), tend to have much more solid flesh, and are multilocular. We do not know of the existence of other parthenocarpic tomato cultivars of this type.

\section{Descriptions}

'Oregon Star' plants are highly determinate, bearing fruit clusters every one or two

Received for publication 17 June 1995. Accepted for publication 27 Jan. 1995. Oregon Agricultural Expt. Station technical paper no. 10,513. The cost of publishing this paper was defrayed in part by the payment of page charges. Under postal regulations, this paper therefore must be hereby marked advertisement solely to indicate this fact. nodes; plants become 1.0 to $1.2 \mathrm{~m}$ across at maturity. Early season fruit set is mostly parthenocarpic, resulting in early set, usually on the first flower to open, and a crop of fruit that is $\geq 60 \%$ completely seedless, depending on environmental conditions. First fruit ripen in Corvallis, Ore., $\approx 87$ to 90 days after mid-May transplanting, compared to 77 days for 'Santiam', 81 for 'Oregon Spring', 98 for 'Willamette', 94 for 'Early Girl', and 107 for 'Celebrity' and 'Sunny'. The fruit (Fig. 2) typically are borne four per cluster. Early fruit tend to be globular in shape and large, $\leq 12 \mathrm{~cm}$
Fig. 1. Pedigree of 'Oregon Star' and 'Oregon Pride' tomatoes.

Fig. 2. 'Oregon Star' fruits showing the solid, seedless interiors. in diameter, with some weighing $>700 \mathrm{~g}$. Fruit shape changes gradually as the season progresses; later fruit are lemon-shaped, 10 $\mathrm{cm}$ long $\times 8 \mathrm{~cm}$ wide, and weigh $100 \mathrm{~g}$. Average fruit weight in trials has been $\approx 230 \mathrm{~g}$, compared to $127 \mathrm{~g}$ for 'Oregon Spring', $185 \mathrm{~g}$ for 'Pickred', and $200 \mathrm{~g}$ for 'Celebrity'. Fruit are firm without being tough and are highly multilocular with small locules. Individual locules rarely are dry or necrotic. Individual fruit are slow ripening, long keeping, and slow to soften. Flavor is mild and has been well accepted by growers.

'Oregon Pride' is generally similar to 'Oregon Star'. Fruit are indistinguishable, but first fruit ripen $\leq 1$ week earlier, the crop peaks earlier, and the plant is smaller (0.7 to $0.8 \mathrm{~m})$ and provides less fruit cover. The range in fruit size is similar to that of 'Oregon Star', but the average size of 'Oregon Pride' fruit is smaller $(\approx 160 \mathrm{~g})$.

'Oregon Star' and 'Oregon Pride' fruit resemble paste tomatoes in shape, and internal solidity is equal to or greater than that of typical paste cultivars. In preliminary determinations, total solids content $(5.5 \%)$ has not
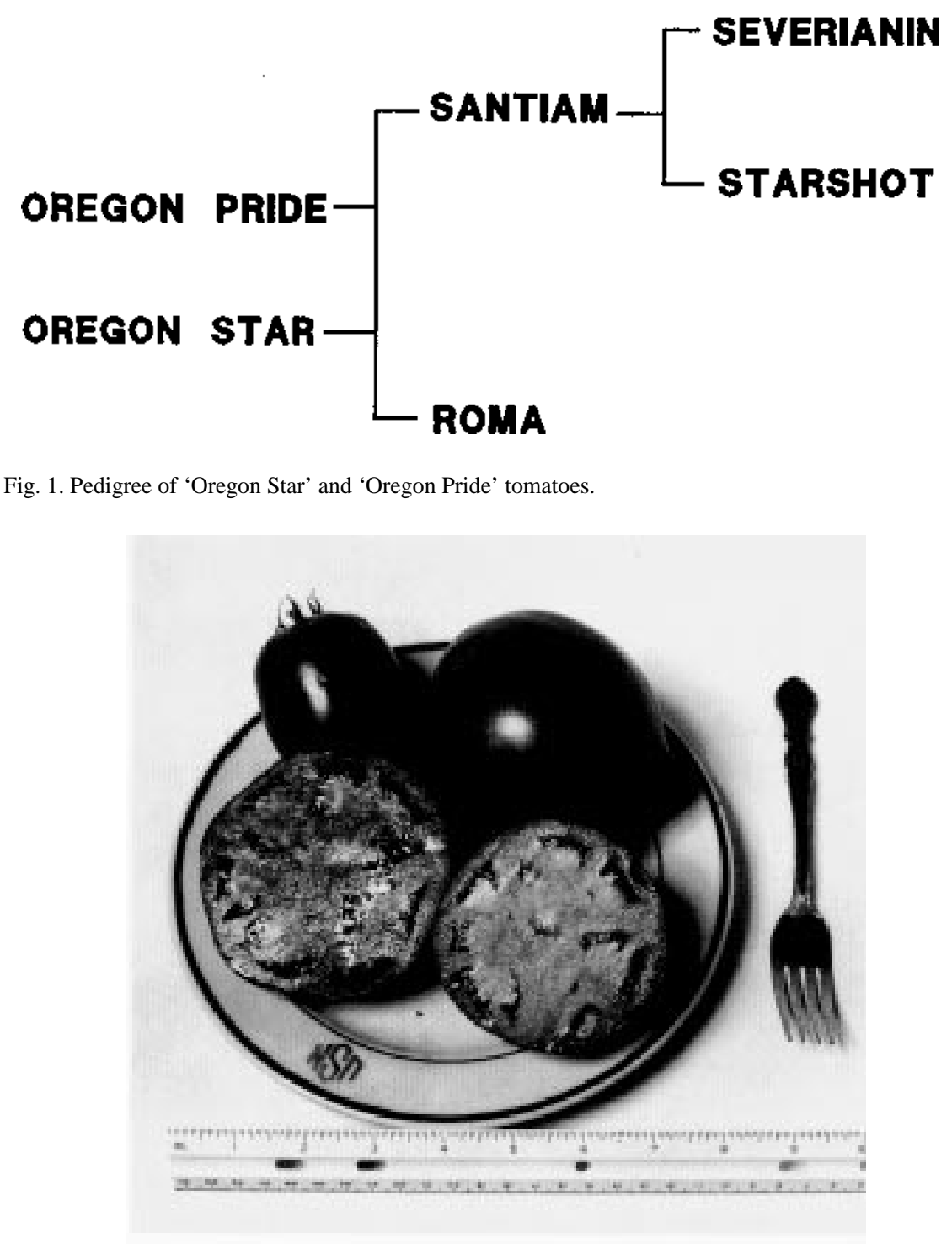
been consistently higher than that of allpurpose tomatoes 'Oregon Spring' and 'Santiam', but the consistency of the raw or cooked puree has resembled that of paste tomatoes. Because of their large fruit size, they are highly acceptable for table use, and we recommend them as all-purpose cultivars.

The occurrence of seeds in 'Oregon Star' and 'Oregon Pride' fruit varies with season and location. Normally, in Corvallis, $>50 \%$ of the fruit are totally seedless with May transplanting. In some seasons, only the latest ripening, smallest fruit are seedy, but usually seeds are present in about the last $25 \%$ of the fruit to ripen. Even seedy fruit produce a relatively low seed yield because of the solid internal structure and small locules.

When 'Oregon Star' and 'Oregon Pride' are grown under low-temperature conditions, such as in protected April plantings at Corvallis, the fruit, especially the early globose fruit, may be rough in the shoulder. They are susceptible to moderate, usually short, radial cracks when exposed to rain. These cultivars are resistant to race 1 of verticillium wilt (Verticillium dahlii Kleb.).

\section{Availability}

Trial and stock seeds are available from J.R.B., Dept. of Horticulture, Oregon State Univ., Corvallis, OR 97331-7304.

\section{Literature Cited}

Baggett, J.R. and D. Kean. 1986. 'Oregon Spring' and 'Santiam' parthenocarpic tomatoes. HortScience 21:1245-1247.

Philouze, J. and B. Maisonneuve. 1978. Heredity of the natural ability to set parthenocarpic fruit in the Soviet variety Severianin. Tomato Genet. Coop. Rpt. 28:12-13. 